\title{
Mastitis Detection System in Dairy Cow Milk based on Fuzzy Inference System using Electrical Conductivity and Power of Hydrogen Sensor Value
}

\author{
Muhammad Syahrial Rukmana, Andrian Rakhmatsyah, \\ Aulia Arif Wardana \\ School of Computing, Telkom University, Bandung, Indonesia \\ Email : syahrialr@student.telkomuniversity.ac.id, \\ kangandrian@telkomuniversity.ac.id, auliawardan@telkomuniversity.ac.id \\ Received March 3, 2021; Revised April 26, 2021; Accepted May 29, 2021
}

\begin{abstract}
This study build a system for screening method to detect mastitis in dairy cow milk using Electrical Conductivity (EC) and Power of Hydrogen $(\mathrm{pH})$ sensor. The value of $\mathrm{EC}$ and $\mathrm{pH}$ sensor is analyze using fuzzy logic to clarify the truth value between it. Mastitis in cows can cause loss and decrease milk production and quality in the dairy farmer industry. Currently, detecting mastitis in cow's milk still done manually by looking at the color change of the milk and analyzing the cow behavior. This paper has designed a mastitis detection system using the Mamdani type fuzzy inference system and the final result will be displayed on an Android-based smartphone. From the test result, it was found that the system has $79.2 \%$ detection accuracy value. This system is suitable for alternative screening method that used to detect mastitis in dairy cow milk.
\end{abstract}

Keywords: mastitis, cow milk, fuzzy inference system, electrical conductivity, power of hydrogen.

\section{INTRODUCTION}

Mastitis in cows can result loss of a lot of milk in the dairy farming industry. This loss results in a decrease in the production of milk. Mastitis caused by bacteria on the nipple of a cow that occurs when the udder (milk gland) becomes inflamed which can lead to invasion of the nipple canal. These bacteria reproduce by producing toxins that cause injury to the milk-secreting tissues and various ducts throughout the mammary glands. This causes a reduction in milk production and changes the milk content. These changes adversely affect the quality and quantity of dairy products produced [1].

The research [2] explains about clinical and sub-clinical mastitis of small dairy farming. Infectious pathogens are generally found to be more common than environmental pathogens. The difference in disease prevalence can be linked to management factors at the farm level. An understanding of the impact and awareness of mastitis for farmers and animal health workers resulting in a marked increase in knowledge of the disease and its control. This 
knowledge should be the basis of mastitis prevention to achieve a sustainable improvement in udder health is essential in the dairy farming system.

Therefore it is necessary to have an alternative system that is used to solve problems that can affect the quality of the cow's milk. Especially in the process of screening for detecting mastitis in cows milk. There are several ways to detect mastitis in cow's milk. First, the research [3] [4] explain the measurement of the potential data value of the electrical conductivity (EC) of milk as a mastitis screening test. Infection status was determined by bacteriological analysis of the foremilk sample. The infection is classified as a mastitis pathogen depending on the organism being isolated as a mastitis pathogen. Mastitis increases EC milk due to damage to udder tissue by a number of pathogens. This increases the concentration and decreases the chemical compounds in milk. EC milk samples have a high correlation with mastitis. This parameter is very effective for diagnosing an udder health.

Secondly, the research [5] [6] explain that good milk can easily be detected by looking at the color of milk and measuring the $\mathrm{pH}$. Good milk will be white or yellowish white in color with a pH range of 6.7-6.9. PH testing can be considered as a way of detecting mastitis because it is economical, cheap and fast because it can be done immediately after milking. The sensor values of EC and $\mathrm{pH}$ are related to one another. In research [7] and [8], there are significant correlation between somatic cell count (SCC), EC, and pH for for diagnosis of subclinical and clinical mastitis in cow milk. It means the value of SCC, EC, and pH are dependent to diagnose the mastitis in cow milk. Lastly, in research [9] used combination of SCC, $\mathrm{pH}$ and EC for screening method to detect mastitis in cow milk. The value of $\mathrm{pH}$ and EC will significant increase when the cow milk infected by mastitis.

Based on those, this research build a mastitis detection tool based on EC and $\mathrm{pH}$ value, obtained from $\mathrm{EC}$ and $\mathrm{pH}$ sensor. The $\mathrm{EC}$ and $\mathrm{pH}$ sensor is connected to the microcontroller. The sensors are used to collect data for support realtime data analysis program in the cloud. The method used to analyze and classify the data obtained from the sensor is fuzzy inference system. In [10] research, the theory of fuzzy systems can be useful in assessing some of the more conventional and less complex systems. For example, for some problems with unclear solutions. Close solution but fast, can be useful in making initial design decisions; or as a preliminary estimate in more accurate numerical techniques to save computing costs; or in situations where the input to a problem is vague, ambiguous, or completely unknown.

This paper is organized as follows, the introduction section describes the problem of mastitis milk and the detection system that has been built. The related work section discusses papers related to the use of technology in the detection and application of the fuzzy inference system method. The proposed method section describes about how the system works and system design. The experiment and analysis section describes the result of experiment and performance analysis. The last, in conclusion section describes the coclusion of the experiment in this research. 


\section{RELATED WORKS}

Fuzzy logic, one of which can be used to explain the development of a classification model and mastitis control for dairy cows that uses an automatic milking system. Mastitis warning with fuzzy logic model uses parameters of electrical conductivity, milk production rate, and milk flow rate. Then evaluate the model according to sensitivity, specificity and error rate [11] [12][13][14]. The other method is using neuro fuzzy method to analyze data from multi value parameter to predict mastitis. The parameter that used in the prediction method is milk yield, EC, average milking duration, and SCC. The detection method used for predict subclinical mastitis in dairy cattle [15].

Other research using combination of multi sensor to detect mastitis online and automatically in goat milk. The parameter that used is milk yield, average EC in milking session, $\mathrm{pH}$ of milk, temperatures of milk, milk production efficiency between successive milking sessions, milking time, milking efficiency, milk production time, and cow number. The data from multiple sensor analyze using Learning vector quantization (LVQ) neural network [16]. The detection and prediction of mastitis using EC or $\mathrm{pH}$ especialy not just in cow milk, but in other farm animals milk like sheep, goat, and camel. The method that used to analyze the data is also variative [17][18][19]. Fuzzy Inference System is just one method that good to predict and detect the mastitis [11][12].

Based on previous research, there are no mastitis detection systems based on EC and pH parameters using a fuzzy inference system. This research just used $\mathrm{pH}$ and EC sensor because to reduce the cost. Based on previous research, this two sensor is enough to detect mastitis. This research is expected to help breeders in developing countries, especially Indonesia, to detect mastitis with good technology and low prices. In this study, the mastitis detection system was used to screen for mastitis that occurs in cow's milk. In addition, this study also uses the concept of realtime analysis using Internet of Things (IoT) technology. With IoT techology, all data from the sensor will be analyzed and sent to the cloud so that it can be seen on the mobile application in realtime.

\section{ORIGINALITY}

This research proposed a system for screening method to detect mastitis in dairy cow milk using Electrical Conductivity (EC) and Power of Hydrogen (pH) sensor. The value of $\mathrm{EC}$ and $\mathrm{pH}$ sensor is analyze using fuzzy logic. This research uses standard hardware and has a low cost. The system built is also equipped with an IoT system to view data in real time and store data periodically on the cloud server. It is hoped that this research can be used in developing countries to assist cattle farmers in producing good quality milk and detecting mastitis in cows easily and quickly. 


\section{SYSTEM DESIGN}

\subsection{General System Process}

The system in this reserach can formulate the mapping process from input to output using fuzzy logic. This mapping provides a basis for identifying mastitis in dairy cows based on where decisions can be made or patterns seen. The fuzzy inference system design for building this system uses the Mamdani method. There are two parameters used, called value of the electrical conductivity (EC) sensor in milisiemens / centimeter and the $\mathrm{pH}$ of the milk. Each parameter is classified under several conditions. The final results of system testing is done by measuring changes in value and $\mathrm{EC}$ and $\mathrm{pH}$ in dairy cow's milk which will diagnose mastitis or not which is displayed on the android or smartphone application. The pH sensor type that used in this research is DFRobot SEN0161 Gravity: Analog pH Sensor / Meter Kit For Arduino. The EC sensor type that used in this research is DFRobot Gravity: Analog Electrical Conductivity Sensor / Meter $(K=10)$.

Figure 1 describes the process flow in the mastitis detection system in dairy cow's milk as an illustration of the way the system is built starting with an electrical conductivity probe (EC) and $\mathrm{pH}$ immersed in a container containing cow's milk that is not known wether infected with mastitis or not. Data collection is carried out by sensors according to predetermined parameters, but if the sensor fails to collect data, the system will repeat data retrieval from the $\mathrm{EC}$ and $\mathrm{pH}$ probes.

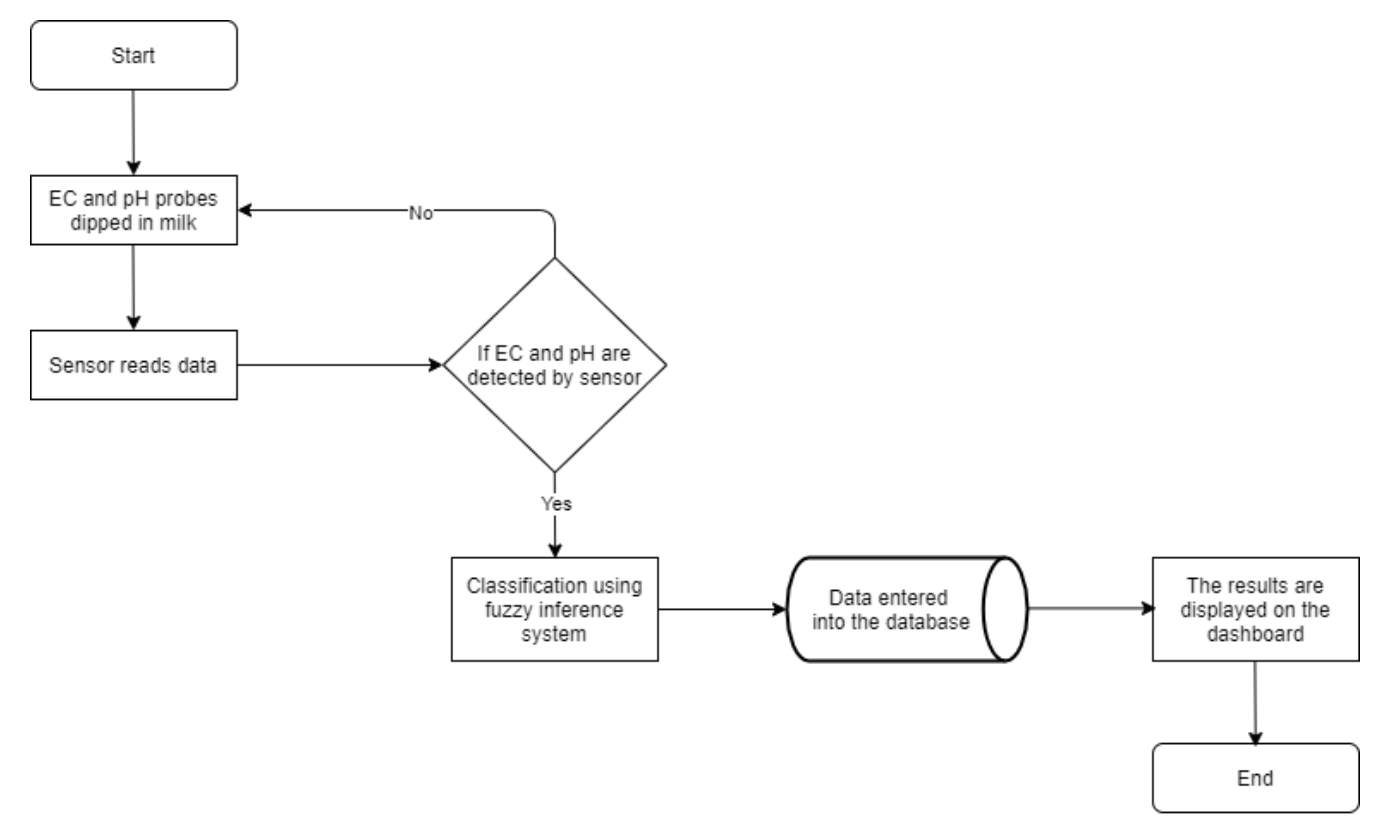

Figure 1. System process flow

As said in research [20], IoT technology can retrieve data in real time from the physical world. Data from the physical world is taken from sensors and stored in the cloud for analysis. The research [21] explain about the used of cloud service and TCP/IP network for realtime data monitoring. The cloud 
service and TCP/IP network is the importtant component in IoT system. It suitable for used in online realtime data monitoring. The sending format commonly used to transmit data on IoT is JSON. As in [22] research, JSON is a format that is often used to transmit data on IoT technology. JSON has an easyto-read format and lightweight to use in IoT network. So, this research implement IoT technology to perform realtime data analyasis with readable for user. Beside, IoT technology can make data analysis that can be accessed directly via the internet from anywhere and anytime.

Data from the parameters obtained from the sensor then classified using the fuzzy inference system and then stored in Firebase which then visualized via smartphone dashboard or user interface like in Figure 2. The system can measure electrical conductivity (EC) and $\mathrm{pH}$ using an electrical conductivity sensor and an analog $\mathrm{pH}$ meter sensor to get the $\mathrm{ms} / \mathrm{cm}$ unit value and $\mathrm{pH}$ value. Data that has been received by the microcontroller is processed using the fuzzy inference system method using the Embedded Fuzzy Logic Library on the microcontroller. Then the data is sent to the Firebase Realtime Database. The dashboard displays the final result analysis in the form of a decision whether the dairy cow has mastitis or not.

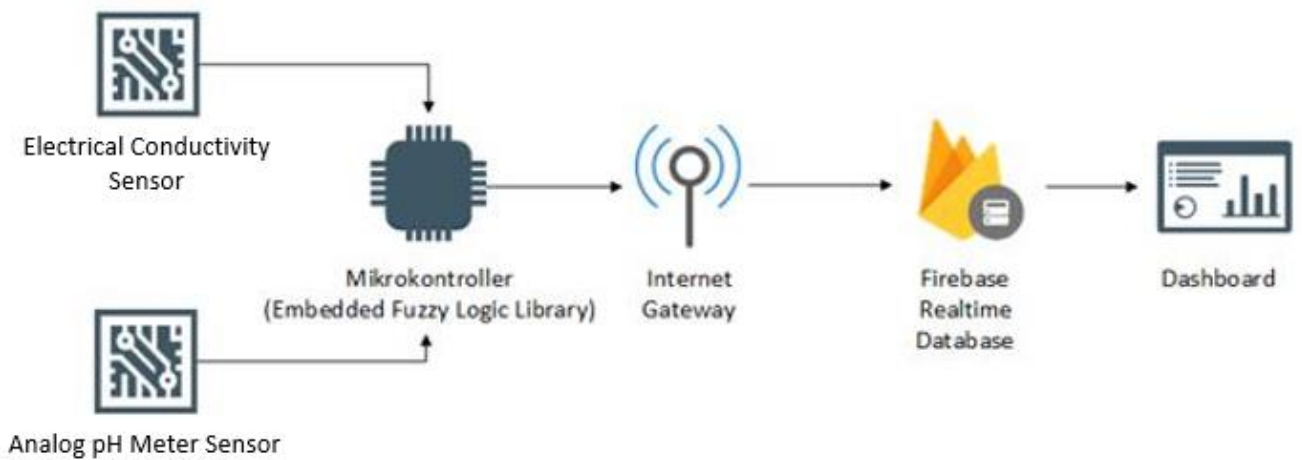

Figure 2. System model

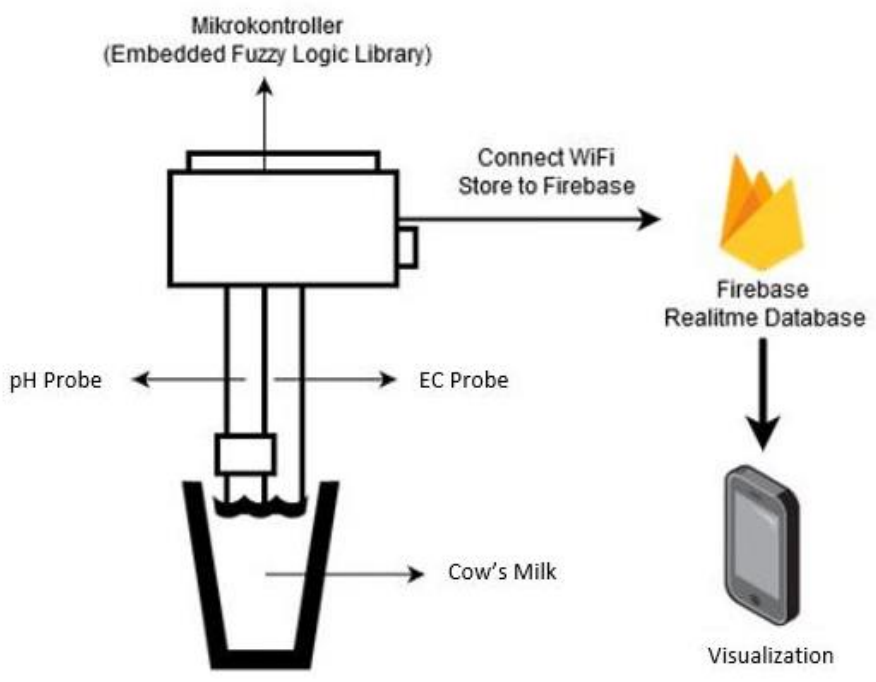

Figure 3. Block diagram 
Figure 3 describes the tests carried out on reading data or parameters from the sensor in real time that dipped in a container for storing dairy cow's milk. Then EC and pH values are obtained for analysis using embedded fuzzy logic which will make decisions wether dairy cows is infected with mastitis or not. After that, the data will be sent to Firebase.

\subsection{Fuzzy Model and Design}

In this research, the Mamdani fuzzy model is used as a decision maker to determine whether a cow has mastitis or not. Testing is done through testing a sample of milk from the cow. The architecture of this system is shown in the Figure 4 schema. The fuzzy logic model allows representing the system under study to consider the input and output variables through fuzzy sets represented by linguistic terms. The fuzzy model for this system consists of two input variables and one output variable, with an inference rule of nine.

The form of the membership function used in the input variable is trapezoid, while in the output variable, the trapezoid and triangular membership function is used. According to research [23], shape characteristics for membership function, triangular shape are better used in efficiency of space complexity, memory and arithmetic performance. The parameters for $\mathrm{pH}$ and $\mathrm{EC}$ that have been determined are still gray parameters. There are 4 parameters for each membership function so that the FK is trapezoidal. Research [24] states that the trapezoidal shape is better for calculating the accuracy value so that in this study the trapezoidal membership function is created. Based on the researchers' assumptions, because the EC and $\mathrm{pH}$ variables are dependent variables, the membership function is made the same, namely trapezoid.

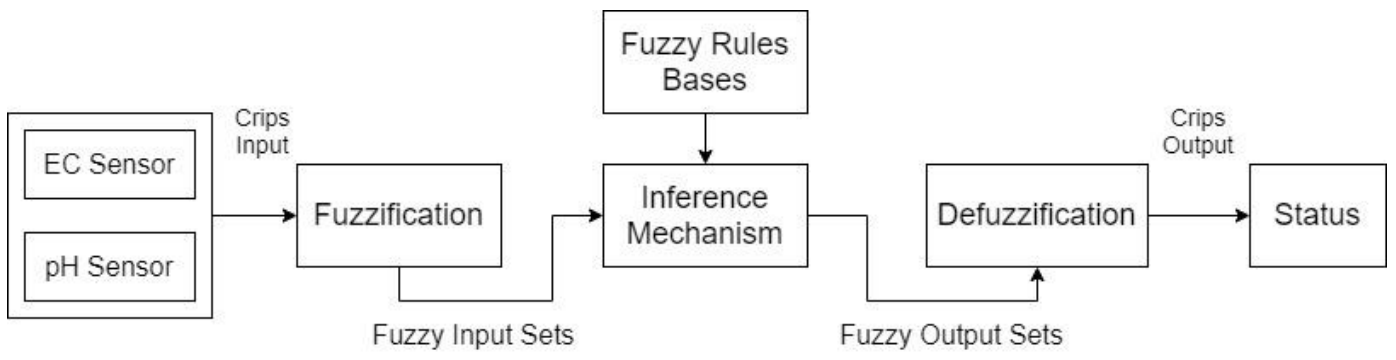

Figure 4. The fuzzy logic model of the detection of Mamdani type mastitis considers three stages: fuzzification, inference mechanism and defuzzification.

Next, input and output variables and the model inference rules are detailed. The modeling in this system uses nine linguistic variables (input and output) with their respective fuzzy sets, where the values have been set. Based on previous research [4] [23], Table 1 shows the concentration of the linguistic variables of the model. 
Table 1. Description of linguistic variables and fuzzy sets and their values.

\begin{tabular}{|c|c|c|c|}
\hline $\begin{array}{c}\text { Linguistik Variable I } \\
\text { (Input) and O (Ouput) }\end{array}$ & Description & Fuzzy Set & Value \\
\hline $\begin{array}{c}\text { Electrical Conductivity } \\
\text { (EC) (I) }\end{array}$ & $\begin{array}{c}\text { Electrical } \\
\text { conductivity } \\
\text { measurement } \\
\text { in cow's milk }\end{array}$ & $\begin{array}{c}\text { Low } \\
\text { Moderate } \\
\text { High }\end{array}$ & $\begin{array}{c}5.5-6.5 \mathrm{~ms} / \mathrm{cm} \\
\geq 7.5 \mathrm{~ms} / \mathrm{cm}\end{array}$ \\
\hline $\mathrm{pH}(\mathrm{I})$ & $\mathrm{pH}$ & Low & $\leq 6.4$ \\
& measurement & Normal & $6.5-6.7$ \\
& High & $\geq 6.8$ \\
\hline Status (O) & Hew's milk & Abnormalth & $\leq 20 \%$ \\
& diagnosis of & Healthy & $50 \%$ \\
& cow's milk & Mastitis & $\geq 80 \%$ \\
\hline
\end{tabular}

\subsection{Input Variable}

\subsubsection{Electrical Conductivity}

Electrical conductivity is a variable that refers to the ability of a spout to carry an electric current, this variable is important because its increase or decrease has the consequence of a reading that is carried out by capturing positive and negative ions from a solution. The electrolyte value of a solution can change due to body and environmental conditions. Become more practical and easy to know by using EC [25].

For this variable, three expressions are converted into linguistic variables which refer to the conductivity $\mathrm{ms} / \mathrm{cm}$, and each defines a fuzzy set, namely:

- High fuzzy set if the electrical conductivity is very high, it refers to the electrical conductivity delivered to the milk $\geq 7.5 \mathrm{~ms} / \mathrm{cm}$. The higher the electrical conductivity, the milk is not suitable for distribution.

- Moderate fuzzy set electrical conductivity to be medium. The conductivity between $5.5 \mathrm{~ms} / \mathrm{cm}$ and $6.5 \mathrm{~ms} / \mathrm{cm}$ is considered acceptable.

- Low fuzzy set electrical conductivity set. EC $\leq 3.0 \mathrm{~ms} / \mathrm{cm}$. Low electrical conductivity, possibly the milk is abnormal.

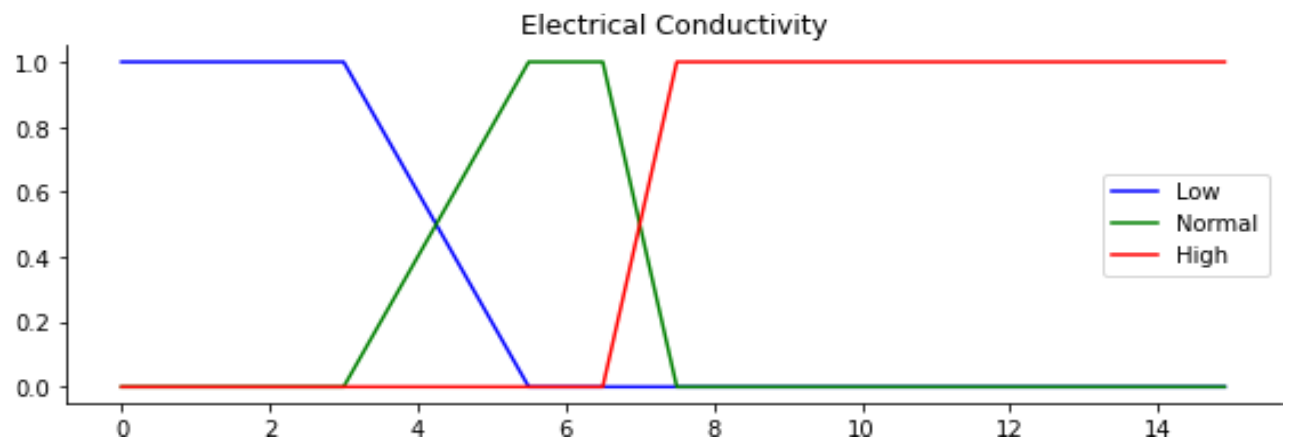

Figure 5. A collection of representations of fuzzy input variables using the trapezoidal membership function: Electrical Conductivity. 
Figure 5 shows three fuzzy sets for this variable if the value of the EC variable is less than or equal to $3.0 \mathrm{~ms} / \mathrm{cm}$, indicating the Low fuzzy set, the EC variable value between $5.5 \mathrm{~ms} / \mathrm{cm}$ and $6.5 \mathrm{~ms} / \mathrm{cm}$ is the fuzzy Moderate set. If the value of the EC variable is equal to or greater than $7.5 \mathrm{~ms} / \mathrm{cm}$, that is, the High fuzzy set and as in the case of the Moderate EC fuzzy set has a value between $5.5 \mathrm{~ms} / \mathrm{cm}$ and $6.5 \mathrm{~ms} / \mathrm{cm}$ partly a fuzzy Moderate set and to some extent a fuzzy set High with the membership degrees of $\mu$ Moderate (EC) and $\mu$ High (EC). Eq. (1) - (3) is a predefined set function:

Low: $\left\{\begin{array}{c}1 ; U \leq 3.0 \\ 1-\frac{U-3.0}{5.5-3.0} ; 3.0<U<5.5 \\ 0 ; U \geq 5.5\end{array}\right.$

Eq 1. Variabel Electrical Conductivity, set fuzzy Low

Moderate: $\left\{\begin{array}{c}0 ; U \leq 3.0 \\ 1-\frac{5.5-U}{5.5-3.0} ; 3.0<U<5.5 \\ 1 ; 5.5 \leq U \leq 6.5 \\ 1-\frac{U-6.5}{7.5-6.5} ; 5.5<U<7.5 \\ 0 ; U \geq 7.5\end{array}\right.$

Eq 2. Variabel Electrical Conductivity, set fuzzy Moderate

High: $\left\{\begin{array}{c}0 ; U \leq 6.5 \\ 1-\frac{7.5-U}{7.5-6.5} ; 6.5<U<7.5 \\ 1 ; U \geq 7.5\end{array}\right.$

Eq 3. Variabel Electrical Conductivity, set fuzzy High

\subsection{2 $\mathrm{pH}$}

The $\mathrm{pH}$ variable in milk is important in testing for faeces, putrefaction, and signs of mastitis infection. Although there are a number of factors that influence the composition of milk, measuring the $\mathrm{pH}$ can help cattle ranchers understand what might be causing a particular composition change. $\mathrm{PH}$ measurements are generally carried out at various points in a milk processing plant [26]. For this variable, three linguistic expressions are considered, and each of them defines the fuzzy set, namely:

- High pH fuzzy set is obtained from milk with a $\mathrm{pH}$ value of $\geq 6.8$ and this indicates that the milk comes from cows with mastitis infection.

- Normal pH fuzzy set obtained from milk with a pH value of 6.5 - to 6.7 is suitable for distribution.

- Low pH fuzzy sets are obtained when the $\mathrm{pH}$ value of milk is $\leq 6.4$, usually indicating spoilage by bacterial degradation. 


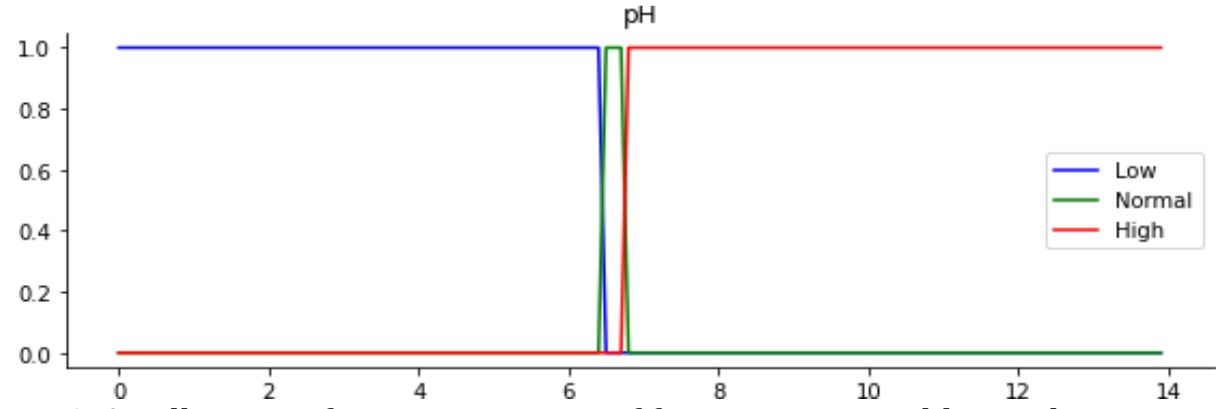

Figure 6. A collection of representations of fuzzy input variables with trapezoidal membership functions: $\mathrm{pH}$

Figure 6 shows the fuzzy set for $\mathrm{pH}$ measurement. The low ph fuzzy set, when it has a value of $\leq 6.4$ and value between 6.4 and 6.5 it belongs partly to the fuzzy ph low set, and to some extent to the regular fuzzy set $\mu \mathrm{Low}(\mathrm{pH})$ and $\mu \operatorname{Normal}(\mathrm{pH})$. When the value is 6.5 to 6.7 it is included in the normal pH fuzzy set. The values ranging between 6.7 and 6.8 partially belong to the high $\mathrm{pH}$ fuzzy set and to some extent to the high, $\mu$ Normal $(\mathrm{pH})$ and $\mu$ Base $(\mathrm{pH})$ fuzzy set. The membership function of the $\mathrm{pH}$ variable is shown below in Eq. (4) (6):

Acid: $\left\{\begin{array}{c}1 ; V \leq 6.4 \\ 1-\frac{V-6.4}{6.5-6.4} ; 6.4<V<6.5 \\ 0 ; V \geq 6.5\end{array}\right.$

Eq 4. $\mathrm{pH}$ variable, Low fuzzy set

Normal: $\left\{\begin{array}{c}0 ; V \leq 6.4 \\ 1-\frac{6.4-V}{6.5-6.4} ; 6.4<V<6.5 \\ 1 ; 6.5 \leq U \leq 6.7 \\ 1-\frac{V-6.7}{6.8-6.7} ; 6.7<V<6.8 \\ 0 ; V \geq 6.8\end{array}\right.$

Eq 5. pH variable, Normal fuzzy set

Alkaline: $\left\{\begin{array}{c}0 ; V \leq 6.7 \\ 1-\frac{V-6.7}{6.8-6.7} ; 6.7<V<6.8 \\ 1 ; V \geq 6.8\end{array}\right.$

Eq 6. $\mathrm{pH}$ variable, High fuzzy set

\subsection{Inference Rules}

The inference process is formed by connecting the fuzzy set of input variables of type IF-THEN and output using the AND operator. The final result of the inference process is based on the parameters used to generate the nine inference rules. Several inference rules are shown in Table 2, each combination tabulated regularly. 
Table 2. Fuzzy Inference System Set

\begin{tabular}{|c|c|c|}
\hline \multicolumn{2}{|c|}{ Fuzzy Input Variable Set } & $\begin{array}{c}\text { Fuzzy Output } \\
\text { Variable Set }\end{array}$ \\
\hline $\begin{array}{c}\text { Electrical } \\
\text { Conductivity } \\
\text { (EC) }\end{array}$ & pH & Status \\
\hline Low & Low & Abnormal \\
\hline Low & Normal & Healthy \\
\hline Low & High & Abnormal \\
\hline Modderate & Low & Healthy \\
\hline Modderate & Normal & Healthy \\
\hline Modderate & High & Mastitis \\
\hline High & Low & Mastitis \\
\hline High & Normal & Mastitis \\
\hline High & High & Mastitis \\
\hline
\end{tabular}

\subsection{Output Variable}

The output variable is the result of the combination of each input variable. Variables are qualified by assigning different fuzzy sets for each variable. Then a detailed description of the fuzzy variables and sets can see in Figure 7. The category of fuzzy output value is like Eq. (7) - (9).

Abnormal: $\left\{\begin{array}{c}1 ; V \leq 0.2 \\ 1-\frac{V-0.2}{0.5-0.2} ; 0.2<V<0.5 \\ 0 ; V \geq 0.5\end{array}\right.$

Healthy: $\left\{\begin{array}{c}0 ; V \leq 0.2 \\ 1-\frac{V-0.2}{0.5-0.2} ; 0.2<V<0.5 \\ 1-\frac{0.8-V}{0.8-0.5} ; 0.5<V<0.8 \\ 0 ; V \geq 0.8\end{array}\right.$

Mastitis: $\left\{\begin{array}{c}0 ; V \leq 0.5 \\ 1-\frac{0.8-V}{0.8-0.5} ; 0.5<V<0.8 \\ 1 ; V \geq 0.8\end{array}\right.$

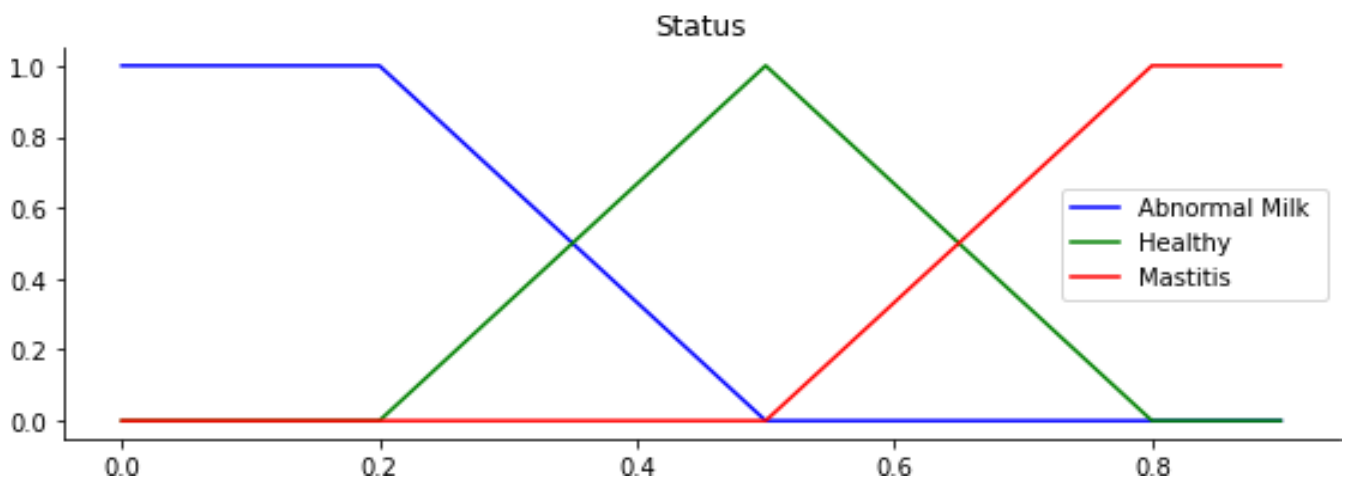

Figure 7. Set fuzzy representation of output variables: Milk status 


\subsection{Defuzzification Method}

The defuzzification criterion used is Maximum-Minimum. To determine the ownership level of the fuzzy output set, first calculate the minimum value of the fuzzy set of input variables for the activated rule. In case two or more activated rules come to the same conclusion, the maximum value of the rule ownership degree must be obtained with the same conclusion. The defuzzification method used is the center of gravity or centroid, which calculates the center of the area. To calculate the center of gravity algorithm, divide the function into equal parts and calculate by adding up all the points.

\section{EXPERIMENT AND ANALYSIS}

\subsection{Test Result}

Prior to testing, milk was brought from the farmer who was at the BKBLK Kertawangi Farm, Cisarua, Bandung Regency. The first test scenario is carried out to calibrate the tool by looking for a comparison between the difference in $\mathrm{pH}$ in the system and the $\mathrm{pH}$ meter commonly used by breeders, then the error value is calculated using the equation (10). In this scenario, testing is carried out to obtain the difference in $\mathrm{pH}$ values. The test results are shown in Table 3.

$N E(\%)=\frac{(p H \text { Meter }-p H \text { Sistem }) \times 100}{p H \text { Meter }}$

The second test scenario is carried out to calculate the accuracy of the comparison of the final results between the cow's milk sample and the mastitis detector. This test was carried out on 6 dairy cows with a total of 24 samples. Based on the assumptions obtained from the farmer regarding the condition of the cow's milk sample, 20 milk samples were declared healthy and 4 milk samples were declared mastitis. Testing of the tool is carried out by immersing the electrical conductivity (EC) and $\mathrm{pH}$ sensors to produce the readings displayed on the mastitis detector application. The calculation of accuracy uses formula (11). The test results are shown in Table 4.

Accuracy $(\%)=\frac{\mid \text { Number of Milk Samples }- \text { Result don't match } \mid}{\text { Number of Milk Samples }} \times 100$

Table 3. First Scenario Testing: Comparison of the $\mathrm{pH}$ value of the system with a $\mathrm{pH}$ meter

\begin{tabular}{|c|c|c|c|c|c|c|}
\hline No & Cow Name & Udder & $\mathbf{p H}$ Meter & $\mathbf{p H}$ System & Difference & Error \\
\hline \multirow{4}{*}{1} & & Front Left & 6.6 & 6.5 & 0.1 & $1.52 \%$ \\
\cline { 3 - 7 } & \multirow{3}{*}{ Isna } & Back Left & 6.55 & 6.52 & 0.03 & $0.46 \%$ \\
\cline { 3 - 7 } & & Front Right & 6.55 & 6.69 & 0.14 & $2.14 \%$ \\
\hline & & Back Right & 6.66 & 6.67 & 0.01 & $0.15 \%$ \\
\hline \multirow{3}{*}{2} & \multirow{3}{*}{ Lina } & Front Left & 6.6 & 6.67 & 0.01 & $1.06 \%$ \\
\cline { 3 - 7 } & & Back Left & 6.65 & 6.7 & 0.05 & $0.75 \%$ \\
\cline { 3 - 7 } & & Front Right & 6.65 & 6.5 & 0.15 & $2.26 \%$ \\
\cline { 3 - 7 } & & Back Right & 6.66 & 6.66 & 0 & $0 \%$ \\
\hline
\end{tabular}


Table 4. Second Scenario Testing: Testing tools at the BKB-LK Kertawangi farm

\begin{tabular}{|c|c|c|c|c|c|c|c|}
\hline No & $\begin{array}{c}\text { Cow } \\
\text { Name }\end{array}$ & Udder & $\begin{array}{c}\text { Milk } \\
\text { Sample }\end{array}$ & $\begin{array}{c}\text { EC } \\
\text { Experiment } \\
(\mathbf{m S} / \mathrm{cm})\end{array}$ & $\begin{array}{c}\text { pH } \\
\text { Experiment }\end{array}$ & $\begin{array}{c}\text { Calculation } \\
\text { Result }\end{array}$ & $\begin{array}{c}\text { Comparison } \\
\text { Between Milk } \\
\text { Samples and } \\
\text { Tool Results }\end{array}$ \\
\hline \multirow{4}{*}{1} & \multirow{4}{*}{ Sari } & Front Left & Healthy & 5.67 & 6.63 & Healthy & Compatible \\
\hline & & Back Left & Healthy & 5.67 & 6.65 & Healthy & Compatible \\
\hline & & Front Right & Healthy & 5.67 & 6.63 & Healthy & Compatible \\
\hline & & Back Right & Healthy & 5.67 & 6.64 & Healthy & Compatible \\
\hline \multirow{4}{*}{2} & \multirow{4}{*}{ Zee } & Front Left & Mastitis & 7.69 & 6.93 & Mastitis & Compatible \\
\hline & & Back Left & Mastitis & 7.69 & 6.94 & Mastitis & Compatible \\
\hline & & Front Right & Mastitis & 7.69 & 6.92 & Mastitis & Compatible \\
\hline & & Back Right & Mastitis & 7.69 & 6.87 & Mastitis & Compatible \\
\hline \multirow{4}{*}{3} & \multirow{4}{*}{ Doli } & Front Left & Healthy & 5.89 & 6.51 & Healthy & Compatible \\
\hline & & Back Left & Healthy & 5.89 & 6.54 & Healthy & Compatible \\
\hline & & Front Right & Healthy & 5.89 & 6.33 & Abnormal & Uncompatible \\
\hline & & Back Right & Healthy & 5.89 & 6.52 & Healthy & Compatible \\
\hline \multirow{4}{*}{4} & \multirow{4}{*}{ Joli } & Front Left & Healthy & 5.76 & 6.58 & Healthy & Compatible \\
\hline & & Back Left & Healthy & 5.76 & 6.33 & Abnormal & Uncompatible \\
\hline & & Front Right & Healthy & 5.76 & 6.31 & Abnormal & Uncompatible \\
\hline & & Back Right & Healthy & 5.76 & 6.53 & Healthy & Compatible \\
\hline \multirow{4}{*}{5} & \multirow{4}{*}{ Sari } & Front Left & Healthy & 5.87 & 6.35 & Abnormal & Uncompatible \\
\hline & & Back Left & Healthy & 5.87 & 6.63 & Healthy & Compatible \\
\hline & & Front Right & Healthy & 5.87 & 6.65 & Healthy & Compatible \\
\hline & & Back Right & Healthy & 5.87 & 6.63 & Healthy & Compatible \\
\hline \multirow{4}{*}{6} & \multirow{4}{*}{ Lina } & Front Left & Healthy & 5.64 & 6.6 & Healthy & Compatible \\
\hline & & Back Left & Healthy & 5.64 & 6.32 & Abnormal & Uncompatible \\
\hline & & Front Right & Healthy & 5.64 & 6.57 & Healthy & Compatible \\
\hline & & Back Right & Healthy & 5.64 & 6.56 & Healthy & Compatible \\
\hline
\end{tabular}

\subsection{Test Result Analysis}

The first test scenario shown in Table 3 is a comparison between the $\mathrm{pH}$ value of the system and the $\mathrm{pH}$ meter. The milk sample used in this scenario is different from the tested milk sample in the second scenario because the sampling time is different. Testing of milk samples is only done to find the difference between the $\mathrm{pH}$ and the $\mathrm{pH}$ meter used by the farmer. In the above study, it was found that the average difference value was $1.04 \%$, which means that the comparison between the $\mathrm{pH}$ meter used by the farmer and the $\mathrm{pH}$ meter system can be tolerated so that this calibration is used for testing.

In the second test scenario, the analysis results obtained are based on Table 4, there are 19 appropriate information results and 5 information results that do not match the sample conditions. From the calculation of the accuracy obtained 79.2\%. Unsuitable results were obtained from the milk of Doli cow who is front-right, Joli is back-left and right-front, Sari is front-left and Lina is back-left. There are several factors that cause the test results to be unsuitable, one of which is the change in $\mathrm{pH}$ to acid so that the device detection changes to be inappropriate. Changes in $\mathrm{pH}$ are caused due to storage for too long there 
is no control on the sample so that some milk samples become acidic and contaminated.

For example, Doli cattle were tested with experimental EC 5.89, and pH 6.43. Decision making using Fuzzy logic for EC 5.89 will produce a fuzzy value with a moderate category of 1 . Whereas for $\mathrm{pH} 6.43$ it will produce an acid category with a value of 0.7 and neutral 0.3 . So after entering into the rules with a moderate EC and low pH the decision was that the milk sample was abnormal.

\section{CONCLUSION}

Based on the results of the research conducted, it is concluded that the mastitis detection system using the fuzzy inference system method has successfully detected an accuracy value of $79.2 \%$ to diagnose mastitis. Suggestions for further research is to develop a tool so that testing of milk is not carried out openly by dipping one by one sample of milk because testing in this way can cause milk to be contaminated with outside air. Testing to get maximum system accuracy can be added by detecting milk samples using the Milk Checker.

\section{Acknowledgements}

Thank you to BKB-LK Kertawangi Farm, Cisarua, Bandung, West Java, Indonesia for allowing me to do research and testing on their farm so that I can finish making this paper.

\section{REFERENCES}

[1] H. Kim, Y. Min, and B. Cho, Real-time Temperature Monitoring for The Early Detection of Mastitis in Dairy Cattle: Methods and Case Researches, Computers and Electronics in Agriculture, Vol. 162, pp. 119125, 2019.

[2] S. Nirwal, R. Pant, and N. Rai, Analysis of Milk Quality, Adulteration and Mastitis in Milk Samples Collected from Different Regions of Dehradun, International Journal of PharmTech Rresearch, Vol. 5, No. 2, pp. 359-364, 2013.

[3] R. S. Fernando, R. B. Rindsig, and S. L. Spahr, Electrical Conductivity of Milk for Detection of Mastitis, J. Dairy Sci, Vol. 65, No. 4, pp. 659-664, 1982.

[4] F. Shagufta, H. Eram, N. Hafsa, B. Spozhmai, L. Shanza, and L. Sidra, Determination of Mastitis by Measuring Milk Electrical Conductivity, Int. J. Adv. Res. Biol. Sci, Vol. 3, No. 10, pp. 164-171, 2016.

[5] H. Batavani, R. Asri, and Naebzadeh, The Effect of Subclinical Mastitis on Milk Composition in Dairy Cows, Iran. J. Vet. Res, Vol. 8, No. 320, pp. 205-211, 2007.

[6] E. D. Karimuribo et al., Clinical and Subclinical Mastitis in Smallholder Dairy Farms in Tanzania: Risk, Intervention and Knowledge Transfer, Prev. Vet. Med, Vol. 74, No. 1, pp. 84-98, 2006. 
[7] S. Shekhar et al., Association Between Somatic Cell Count, Electric Conductivity and $\mathbf{p H}$ in Diagnosis of Subclinical Mastitis in Crossbred Cows, Indian Journal of Veterinary Sciences \& Biotechnology, Vol. 13, No. 3, 2018.

[8] B. Champak, Low Cost Management Practices to Detect and Control Sub-Clinical Mastitis in Dairy Cattle, 2019.

[9] A. Aarif et al., Metabolic Profiling of Dairy Cows Affected With Subclinical and Clinical Mastitis, Journal of Entomology and Zoology Studies, Vol. 5, No. 6, 2017.

[10] T. J.ROSS, Fuzzy Logic With Engineering Application. Ed. 3, 2010.

[11] D. Cavero, K. H. Tölle, C. Buxadé, and J. Krieter, Mastitis Detection in Dairy Cows by Application of Fuzzy Logic, Livestock Science, Vol. 105, No. 1-3, pp. 207-213, 2006.

[12] E. Kramer et al., Mastitis and Lameness Detection in Dairy Cows by Application of Fuzzy Logic, Livestock Science, Vol. 125, No. 1, 2009.

[13] Çoşkun, Fatma Sinem, and Uğur Zülkadir, The Use of Fuzzy Logic Approach in Evaluation of Subclinic Mastitis, Selcuk Journal of Agriculture and Food Sciences, Vol. 32, No. 3, 2018.

[14] Mikail, Nazire, and Ismail Keskin, Subclinical Mastitis Prediction in Dairy Cattle by Application of Fuzzy Logic, 2015.

[15] Mammadova, M. Nazira, and Ismail Keskin, Application of Neural Network and Adaptive Neuro-fuzzy Inference System to Predict Subclinical Mastitis in Dairy Cattle, Indian Journal of Animal Research, Vol. 49, No. 5, 2015.

[16] T. Fuyang et al., An Automated On-line Clinical Mastitis Detection System Using Measurement of Electrical Parameters and Milk Production Efficiency, Journal of Physics: Conference Series, Vol. 1676, No. 1, 2020.

[17] Gelasakis, I. Athanasios et al., Prediction of sheep milk chemical composition using milk yield, $\mathrm{pH}$, electrical conductivity and refractive index, The Journal of Dairy Research, Vol. 85, No. 1, 2018.

[18] Cais-Sokolińska, Dorota et al., Analysis of Metabolic Activity of Lactic Acid Bacteria and Yeast in Model Kefirs Made from Goat's Milk and Mixtures of Goat's Milk with Mare's Milk based on Changes in Electrical Conductivity and Impedance, Mljekarstvo, Vol. 67, No. 4, 2017.

[19] Hadef, Leyla, Brahim Hamad, and Hebib Aggad, Effect of Subclinical Mastitis on Milk Yield and Milk Composition Parameters in Dairy Camels, Acta Biologica Szegediensis, Vol. 63, No. 2, 2019.

[20] A. A. Wardana et al., Internet of Things Platform for Manage Multiple Message Queuing Telemetry Transport Broker Server, Kinetik: Game Technology, Information System, Computer Network, Computing, Electronics, and Control, Vol. 4, No. 3, 2019. 
[21] Bima W, I. W. K., V. Suryani, and A. A. Wardana, Narrowband-IoT network for asset tracking system, Materials Science and Engineering Conference Series, Vol. 830. No. 2. 2020.

[22] Pradana, Muhammad Adna, Andrian Rakhmatsyah, and Aulia Arif Wardana, Flatbuffers Implementation on MQTT Publish/Subscribe Communication as Data Delivery Format, 6th International Conference on Electrical Engineering, Computer Science and Informatics (EECSI), 2019.

[23] Princy. S, Dhenakaran. S. S, Comparison of Triangular and Trapeziodal Fuzzy Membership Function, J. Comput. Sci. Eng, Vol. 2, pp. 45-61, 2016.

[24] R. K. and D. B. DK Bagri, RK Pandey, GK Bagri, Effect of Subclinical Mastitis on Milk Composition in Lactating Cows, J. Entomol. Zool. Stud, Vol. 6, No. 5, pp. 231-236, 2018.

[25] E. Norberg et al., Electrical Conductivity of Milk: Ability to Predict Mastitis Status, Journal of Dairy Science, Vol. 87, No. 4, 2004.

[26] S. A. Kandeel et al., Ability of Milk pH to Predict Subclinical Mastitis and Intramammary Infection in Quarters from Lactating Dairy Cattle, Journal of Dairy Science, Vol. 102, No. 2, 2019. 